УДК 372

DOI:

Наталія Бутенко, кандидат педагогічних наук, доцент кафедри педагогіки, психології й освітнього менеджменту Херсонського державного університету

\title{
ЕСТЕТИЧНИЙ АСПЕКТ ПРОФЕСІЙНОЇ ПІДГОТОВКИ ВЧИТЕЛЯ
}

У статті розглянуто поняття педагогічної майстерності та ї̈ структура. Проведено аналіз теоретичних праць та практичного досвіду видатних педагогів, які були основоположниками введення цуього поняття. Вони доводили важливість наявності певних особистісних та професійних якостей, які мають бути наявні у майстра педагогічної справи. У процесі дослідження зазначеної проблеми вияснилось, щуо не існує однозначного тлумачення сутності изього поняття. Проте в процесі підготовки майбутнього вчителя варто акцентувати увагу на усіх структурних компонентах, а особливе місце має займати естетичний аспект.

Ключові слова: естетичний аспект; професійна підготовка вчителя; педагогічні навички; особисті та професійні навички; педагоги.

Jim. 5.

Nataliya Butenko, Ph.D.(Pedagogy), Associate Professor of the Pedagogy, Psychology and Educational Management Department Kherson State University

\section{AESTHETIC ASPECT OF PROFESSIONAL TRAINING OF TEACHER}

The article deals with the concept of pedagogical skill and its structure. The analysis of theoretical works and practical experience of the outstanding teachers, who were the founders of the introduction of this concept, has been carried out. They proved the importance of having certain personal and professional qualities that the master of teaching skills should possess.

In the process of studying this problem, it became clear that there is no unambiguous interpretation of the essence of this notion. However, in the process of training a future teacher, it is necessary to focus on all structural components. Spiritual, communicative, organizational, psychological bases belong to the structure of pedagogical skills. A special place in the professional training of a future teacher should take an aesthetic aspect. The young educators should have a well-established aesthetic experience. And this means that in their spiritual arsenal they have to find the appropriate place of those qualities that allow them to gracefully perceive the phenomena of the surrounding reality, to evaluate them in the interconnection of form and content, and to multiply in the cultural and creative process of the value of science, technology and art.

The personal creativity of the teacher plays an important role in the educational process. This confirms the presence of such a component of pedagogical skill as creative bases. Pedagogical creativity is incomparable with any other kind of productive activity. Focusing on the studied and analyzed existing examples of school practice, we can distinguish different types of the teacher's creative behavior: a leader, a generator of pedagogical ideas, an enthusiast, a researcher.

Pedagogical skill is an art of education and upbringing; it is the highest level of the teacher's work. It can be provided only by that graduate who will master the laws of beauty in the system of communication, knowledge and creativity, and who will be able to take them into account in their pedagogical activity.

Keywords: an aesthetic aspect; a professional training of teacher; pedagogical skills; personal and professional qualities; educators.

П остановка проблеми. У системі професійної підготовки та формування педагогічної майстерності працівників освіти актуального значення набуває їх естетичний досвід. Як зазначав один із розробників курсу "Педагогічної майстерності" I.A. Зязюн “Вчитель, його майстерність, його талант - невичерпне джерело багатства народу, який прагне до інтелектуальної, етико-естетичної культури в часи усіляких потрясінь та негараздів. Осмислити в єдності естетичний тезаурус: краса педагогічної дії, краса ораторської дії вчителя майстра, вчителя-оратора - це не просте завдання" [1].

У освітньо-професійній підготовці вчителів ця проблема ще немає повноцінного вирішення і не отримала належного осмислення і тому вимагає послідовного і системного аналізу, виявлення найсуттєвіших закономірностей і умов оволодіння естетичним досвідом майбутніми педагогами.

Аналіз останніх досліджень і публікацій. Важливо зазначити, що проблема сутності 
педагогічної майстерності, іiї формування та необхідного при цьому естетичного досвіду вчителя знайшла певне висвітлення.

У різні історичні періоди вчені-педагоги намагалися дати своє розуміння поняття “педагогічної майстерності”. В історії української педагогічної думки питання педагогічної майстерності вчителя разом з іншими питаннями навчально-виховного процесу посідало одне 3 провідних місць у творчості видатних педагогів.

Формування педагогічної майстерності спирається, насамперед, на концепції відомих педагогів минулого (Я. Коменський, О. Духнович, К. Ушинський, С. Русова, П. Блонський та ін.).

Я.А. Коменський уперше звернувся до питання педагогічної майстерності вчителя, яке вимагає гуманного відношення до дитини, енциклопедичних знань, високої культури вчителя. Про вчителя Я.А. Коменський зазначив наступне “а найкращі 3 поміж людей нехай будуть учителями ...”.

Підходи до поняття педагогічної майстерності знаходимо також у Жан-Жака Руссо. Він зазначав, що педагогічна майстерність має будуватися на глибокому вивченні індивідуальних особливостей дитини. Ж.-Ж. Руссо був переконаний, що мистецтву виховання можна навчитись.

Швейцарський педагог Й.Г. Песталоцці зазначав,що педагог-майстер це вчитель, який постійно самовдосконалюється.

С. Русова сформулювала вимоги до вчителя нової школи, який “не сміє бути якимсь ремісником, а апостолом правди і науки”.

Видатний науковець вітчизняної педагогіки i психології П. П. Блонський пропонував учителю “жити зі школою і дітьми спільним життям”, “залишати глибокий слід у їхніх душах”.

С.Т. Шацький великого значення в педагогічній майстерності надавав професійній техніці вчителя, але "не відкладаючи питання про творчість, ...ми повинні говорити про вміння цю роботу робити” [2].

Першим увів поняття "майстерність вихователя" i "педагогічна техніка" А.С. Макаренко у своїй статті “Деякі висновки 3 мого педагогічного досвіду”.

В.О. Сухомлинський був послідовником розробки цієї проблеми, він продовжив розвиток теорії про педагогічну майстерність. У працях В.О. Сухомлинського "Павлиська середня школа", “Сто порад вчителю”, “Розмова 3 молодим директором школи” та інших він велику увагу приділив майстерності вчителя.

Проблеми педагогічної майстерності розроблялися в працях Ю.П. Азарова, Н.В. Кузьміної, Ю.М. Кулюткіна, В.А. Кан-Каліка, І.А. Зязюна, O.I. Мороза, I.Є. Синиці, А.І. Щербакова та ін.

I.A. Зязюн визначає педагогічну майстерність як комплекс властивостей особистості, що забезпечує самоорганізацію високого рівня професійної діяльності на рефлексивній основі [4].

Невід'ємною умовою прояву педагогічної майстерності вчителя $є$ його сформований естетичний досвід. Це можна проілюструвати таким мудрим афоризмом "Краса всюди вельми бажана гостя" (Гете).

Загальнонаукове та теоретичне значення мають праці вчених, в яких розглядається проблема естетичного аспекту формування особистості та роль естетичного досвіду у професійному становленні особистості (М. Бахтін, В. Бутенко, Л. Губерський, Д. Джола, І. Зязюн, М. Каган, Л. Левчук, В. Мазепа, С. Уланова та iH.).

Виділення невирішених раніше частин загальної проблеми, яким присвячусться означена стаття. Практична діяльність вчителів школи визначає проблеми у проявах педагогічної майстерності. Причиною цього є недостатня основа для формування педагогічної майстерності майбутніх вчителів закладена в процесі професійної підготовки.

Мета статті: проаналізувавши психологопедагогічні дослідження та досвід роботи вчителів школи, визначити особливості естетичного аспекту професійної підготовки вчителя та формування його майстерності.

Реалізація поставленої мети вимагає розв'язання таких завдань:

- уточнити сутність поняття педагогічної майстерності;

- дати характеристику окремим структурним компонентам педагогічної майстерності;

- показати роль естетичного аспекту професійної підготовки вчителя;

- визначити особливості формування естетичного досвіду у майбутніх вчителів.

Виклад основного матеріалу. Варто зауважити, що досвід як педагогічна категорія набуває в умовах освітньої практики нерідко спрощеної інтерпретації. 3 ним пов'язуються знання, вміння і навички, які мають отримати студенти. Проте, сучасний рівень осмислення педагогічного процесу вимагає не лише рішучого відходу від традиційних поглядів, але й визначення сутності цього явища, виходячи з нової філософії освіти, де пріоритетне місце займає особистісне начало. У зв'язку з цим досвід, який набувають студенти, слід розуміти передусім як сукупність 


\section{ЕСТЕТИЧНИЙ АСПЕКТПРОФЕСІЙНОӤПІДГОТОВКИ ВЧИТЕЛЯ}

тих якостей, що дозволяють успішно реалізувати на практиці певний потенціал особистості.

В системі педагогічної освіти таке тлумачення досвіду дає можливість відійти від штампів. Обов'язкових нормативів, репродуктивності відтворення методичних вказівок і порад, сугтєвим чином залучити особистісний потенціал майбутнього вчителя, його почуття, думки, творчі задуми. Звернення до досвіду як внутрішньої генеруючої основи фахівця принципово змінює і вимоги до системи його підготовки, яка має набути все більше індивідуалізованого характеру, тяжіти до синкретичності і концептуальності професійної освітньо-виховної діяльності.

Невід'ємним компонентом професійної підготовки вчителя $\epsilon$ формування його естетичного досвіду. Відомий визначний педагог B.О. Сухомлинський в “Листах до сина" зазначив: “Якщо не поліпшиться виховання, ми наплачемося 3 математикою, електронікою і космосом... Найголовніший засіб самовиховання душі- краса. Краса в широкому розумінні - і мистецтво, i музика, і сердечні відносини з людьми". Це застереження не було почуте вчасно. Тому проблеми духовного розвитку людини сьогодні, по суті, стали обов'язковою умовою виживання суспільства. Усі наші сучасні біди мають, як правило, одну причину - дефіцит культури і моральності, дефіцит доброти і милосердя, краси людських стосунків [1]. Тому ми на основі аналізу розвідок вчених відносно сутності поняття “педагогічної майстерності” дійшли висновку, що однією із складових педагогічної майстерності варто визначити духовні основи.

У сучасній освітній практиці естетичний фактор привертає все частіше увагу фахівців. I це не випадково. Адже приклади розвинених в економічному і культурному відношенні країн переконують у тому, що стимулювання естетичної активності висококваліфікованих спеціалістів стає основою соціального, культурного, технічного, економічного прогресу. Молоді педагоги повинні мати достатньо сформований естетичний досвід. А це означає, що в їх духовному арсеналі повинні знайти відповідне місце ті якості, які б дозволяли витончено сприймати явища навколишньої дійсності, оцінювати їх у взаємозв'язку форми і змісту, примножувати в культуро-творчому процесі цінності науки, техніки, мистецтва тощо.

“Для досягнення найвагомішої естетичної впливовості, для усвідомлення мистецької значущості поведінкової активності перед аудиторією слід відштовхуватись не від самочуття, не від психічних станів, переважно непідвладних волі й свідомості, а від логіки фізичних дій. Правильне іï здійснення здатне рефлекторно відтворювати і відповідну ій логіку почугтів, впливати на психікуз ії підсвідомістю" [1].

Майбутній вчитель, який отримує професійну підготовку повинен бути естетично освіченою людиною, здатною повноцінно засвоювати духовні надбання минулого й використовувати в навчально-виховному процесі як засіб впливу на формуючу особистість учня [5].

Процес формування естетичного досвіду працівників освіти має відбуватися при навчанні бакалаврів так і в умовах магістратури, але тут він має певні особливості [3]. Науково-методична практика забезпечення цього процесу у навчальних закладах України переконує в тому, що естетичний досвід має бути тісно пов'язаний 3 професійною діяльністю, тим змістом педагогічного впливу, який має реалізувати вчитель.

На прикладі вчителів природничих дисциплін можна бачити, що естетичний досвід - це шлях до прекрасного в природі, який допомагає освоїти закони гармонії, цілісності, виразності в предметах і явищах природного середовища.

Реалізація завдання формування естетичного ставлення учнів до природи в значній мірі залежить від особистості вчителя, його обізнаності, культури, педагогічної майстерності. Відомо, що покликання педагога - покликання високе і благородне. I не той вчитель, який отримав педагогічну освіту, а той, у якого учні вчаться, бачать джерело пізнання і творчості.

Професія вчителя передбачає наявність певних особистісних якостей, прояву педагогічного такту, витримки, терпіння, любові до дітей. Варто зазначити, що відсутність таких вольових рис характеру, як цілеспрямованість, рішучість, наполегливість, витримка, дисциплінованість, уміння володіти собою в будьякій ситуації стане на заваді формування майстерності. Бути класним керівником, педагогом-організатором, або керівником гуртка 3 метою формування творчості школярів набагато важче чим бути вчителем-предметником. Для формування педагогічної майстерності керівника гуртка необхідно:

- виховання в собі почуття відповідальності;

- прояв прагнення до активних форм і способів творчої діяльності;

- не приймати рішень, які нездійсненні;

- необхідно оцінювати свої дії, усвідомлювати їх наслідки;

- велика вимогливість до себе;

- постійно тренувати в собі вміння в подоланні внугрішніх і зовнішніх перешкод. 
Захопленість педагога, його ентузіазм, причетність до декоративно-прикладної творчості, педагогічний такт допоможуть захопити дітей мистецтвом, навчать розуміти його і отримувати радість від творчої праці. Особиста творчість вчителя відіграє важливу роль в навчальновиховному процесі. Це підтверджує наявність такої складової педагогічної майстерності як творчі основи.

Творча педагогіка, творчий вчитель - як вони необхідні зараз, коли розгорнулась велика робота по перебудові школи. Можна побудувати технологічно нові школи, створити сучасні кабінети та майстерні, оснащені сучасним обладнанням, надрукувати нові підручники - i не буде нової школи. Все це оживе, запрацює, якщо в школу прийде справжній вчитель-особистість. Тільки тоді загориться факел педагогічної творчості, оживуть педагогічні теорії та системи.

Учитель не може бути, не має права бути рядовим в своїй роботі з дітьми, для яких він може бути ідеалом, прикладом для наслідування.

Видатний педагог А.С. Макаренко своєю діяльністю довів, що суть справи перш за все в організації характеру педагога, вихованні його поведінки, а потім в організації його спеціальних знань і вмінь, без яких ні один вихователь не може бути майстром. Педагогічну спадщину А.С. Макаренко, його досвід необхідно ретельно вивчати та аналізувати, а його закони паралельного педагогічного впливу і динаміки руху колективу повинні стати основними законами любого творчого дитячого колективу.

Педагогічна творчість незрівнянна ні з яким іншим видом продуктивної діяльності. Орієнтуючись на вивчені і проаналізовані наявні приклади шкільної практики можна виділити різні типи творчої поведінки вчителя:

Модель перша - “Лідер”. Так можна назвати педагога, який здатний запропонувати яскраву, цікаву, оригінальну педагогічну ідею і повести за собою педагогічний колектив. В ідеальному випадку таким педагогом повинен бути директор школи. Але це може бути і просто творчий педагог, який при підтримці адміністрації здатний на розгортання колективної педагогічної творчості.

Модель друга - "Генератор педагогічних ідей”. До такого типу творчої особистості можна віднести людину, яка пропонує педагогічні гіпотези і перевіряє їх на практиці навчання та виховання.

Модель третя - “Ентузіаст”. Такий педагог захоплений своєю діяльністю, не знає ні початку ні кінця свого робочого дня. Він захоплений пошуком і залучає до нього учнів.
Четверта модель - “Дослідник”. Такий педагог схильний до постійного вивчення, аналізу фактів педагогічної сфери. Він багаторазово перевіряє себе, створює свої моделі розв'язку проблеми, здатний до теоретичних узагальнень $\mathrm{i}$ висновків.

3 метою подальшого удосконалення системи підготовки у вищій педагогічній школі доцільним $\epsilon$ введення навчального предмету "Педагогічна естетика". Він має охоплювати не лише теоретичні але й практичні аспекти естетикопедагогічної діяльності, допомагати випускнику концептуально осмислити сучасну школу, сприйняти їі як цілісну систему духовних, психологічних, комунікативних відносин.

Висновки та подальші напрями дослідження. На основі аналізу теоретичного та практичного досвіду можна зробити певні узагальнення:

Педагогічна майстерність - це мистецтво освіти і виховання, це найвищий рівень праці вчителя. Його забезпечити може лише той випускник, який опанує закони краси в системі спілкування, пізнання i творчості, зможе враховувати їх в своїй педагогічній діяльності.

Естетичний досвід вчителя та його формування $\epsilon$ пріоритетною проблемою педагогічної науки і практики. У вирішенні зазначеної проблеми особливо важливе місце має зайняти магістратура, яка покликана стимулювати у студентів інтерес та потребу у спілкуванні з прекрасним, допомагати у виявленні естетичного ставлення до професійної діяльності, але цей аспект потребує ще теоретичного та практичного аналізу і узагальнення.

\section{ЛІТЕРАТУРА}

1. Зязюн І.А., Сагач Г.М. Краса педагогічної дії. - К.: Українсько-фінський інститут менеджменту і бізнесу, 1997. - C.4

2. Павленко В.В. Проблеми педагогічної майстерності вчителя у спадщині видатних педагогів / В.В. Павленко // Професійно-компетентнісне ставлення майбутніх педагогів початкової та дошкільної освіти у ВН3: збірник науково- методичних праць / за заг. ред. В.С. Литньова, Н.С. Колесник. - Житомир: Вид-во ЖДУ імені І.Франка, 2011. -304 с. - С.216-224.

3. Педагогічна майстерність сучасного вчителя: теорія і практика: Підручник за кредитно-модульною технологією навчання для бакалаврів / Бєльчева Т.Ф., Ізбаш С.С., Елькін М.В. та ін. - Мелітополь: ТОВ “Видавничий будинок ММД”, 2010. - С. 273-274.

4. Педагогічна майстерність: Підручник/I.А.Зязюн, Л.В.Крамущенко,І.Ф.Кривонос та ін. - К., Вища школа, 1997. $-349 \mathrm{c}$

5. Петько Л. В. Виховання естетичної культури студентів в умовах університету / Л. В.Петько // Наукові 


\section{ТВОРЧА СПІВПРАЦЯ СВЯТОСЛАВА КРУТИКОВА ТА ГЕННАДІЯ САСЬКА В РАМКАХ ХІ МУЗИЧНОГО ФЕСТИВАЛЮ “СТРУНИ ДУШ НАШОЇ”}

записки Бердянського державного педагогічного університету. Серія : Педагогіка : зб. наук. пр. - Бердянськ: ФО-П Ткачук О.В., 2017.-Вип. 1.-С. $262-268$.

\section{REFERENCES}

1. Zyazyun, I. A. \& Sahach G. M. (1997). Krasa pedahohichnoyi diyi [The beauty of Pedagogical Idea]. Kyiv, Ukrainian-Finnish Institute of Management and Business, p.4. [in Ukrainian].

2. Pavlenko, V. V. (2011). Problemy pedahohichnoyi maysternosti vchytelya u spadshchyni vydatnykh pedahohiv [Problems of Pedagogical Mastery of a Teacher in the Heritage of Outstanding Teachers]. Professionalcompetent attitude of future teachers of elementary and pre-school education in higher educational institutions: a collection of scientific and methodical works. Zhytomyr,
(Ed). V.E. Litnova, N.E. Chariot. Publ., of ZhSU named after I. Franko, 304 p., pp.216-224. [in Ukrainian].

3. Belcheva, T. F., Izbash S. S., Elkin, M.V. et al. (2010). Pedahohichna maysternist suchasnoho vchytelya: teoriya i praktyka [Pedagogical skill of a modern teacher: theory and practice]. Textbook on credit-modular technology of training for bachelors. Melitopol: LLC Publishing House MMD, pp. 273-274. [in Ukrainian].

4. Zyazyun, I. A., Kramuschenko, L. V., Kryvonos, I.F. et al. (1997). Pedahohichna maysternist [Pedagogical skills: Textbook]. Kyiv. High School, 349 p. [in Ukrainian].

5. Petko, L.V. (2017). Vykhovannya estetychnoyi kultury studentiv v umovakh universytetu [Education of the aesthetic culture of the students of the university]. Scientific notes of the Berdyansk State Pedagogical University. Series: Pedagogy. Science works. Berdyansk, vol.1, pp. 262-268. [in Ukrainian].

Стаття надійшла до редакції 06.08.2018

УДК 78. 071.1(477)

DOI:

Уляна Молчко, доцент кафедри музикознавства та фортепіано Дрогобицького державного педагогічного університету імені Івана Франка

\section{ТВОРЧА СПІВПРАЦЯ СВЯТОСЛАВА КРУТИКОВА ТА ГЕННАДІЯ САСЬКА В РАМКАХ ХІ МУЗИЧНОГО ФЕСТИВАЛЮ “СТРУНИ ДУШІ НАШОЇ”}

Дослідження розглядає мистеџькі здобутки сучасних украйнських композиторів Святослава Крутикова і Геннадія Саська, з якими галицька культурно-освітня громадськість познайомилася в рамка ХІ музичного фестивалю “Струни душі нашої”. Автор статті аналізує творчі доробки фундаторів національної культури, їх художні експерименти, жанрове різноманіття, стилістичне багатство. У публікації фіксується артистичні персоналї, котрі взяли участь у конщертних проектах, здійснюється аналіз інтерпретацій виконавиів.

Ключові слова: С. Крутиков; Г. Сасько; музичний фестиваль; м. Дрогобич; інтерпретачія.

Jim. 6.

Ulyana Molchko, Associate Professor of the Musicology and Piano Department Drohobych Ivan Franko State Pedagogical University

\section{CREATIVE COOPERATION OF SVYATOSLAV KRUTYKOV AND HENNADIY SASKO IN THE FRAMES OF THE FOURTH MUSIC FESTIVAL “THE STRINGS OF OUR SOUL"}

The research examines the artistic achievements of contemporary Ukrainian composers Svyatoslav Krutykov and Hennadiy Sasko, who entered the arena of Galician cultural and educational community in the framework of the XI musical festival "The Strings of Our Soul". The author analyzes the creative projects of the founders of the national culture, their artistic experiments, genre diversity, and stylistic wealth.

In conducting an all-round review of the 2016 art events held in Galicia, the author scientifically reflects upon the great educational work of the Drohobych organization of the National Union of Composers of Ukraine, which is famous for numerous meetings with prominent architects of the contemporary cultural space. Since 1993, within the frames of the musical festival "The Strings of Our Soul", the concert-portraits of renowned contemporary composers have been held: Mykola Kolessa, Bohdana Filts, Hennadiy Lyashenko, Yevhen Stankovych, Myroslav Skoryk, Lesya Dychko, Mykhaylo Stepanenko, Hennadiy Sasko, Yuriy Sydoryak, Oleksandr Opanasyuk, Mykola Lastovetskiy, Juliusz Juciuk (Poland), Vitaly Godziatskyi, Merziye Khalitova and others. The XI festival "The Strings of Our Soul" hospitably entertained Kyiv composers Svyatoslav Krutykov and Hennadiy Sasko.

The work documents the artists who have participated in concert projects. Namely, the teachers and students of the Drohobych Ivan Franko State Pedagogical University, Drohobych Vasyl Barvinskiy Musical College, Ostap Nyzhankivskiy Children's Music School of Stryi, Roman Savytskiy Children's Art School of Truskavets. The interpretation features by the Galician musicians of the works of S. Krutykov and H. Sasko are described.

The author proves that the meetings of the Kyiv composers S. Krutykov and H. Sasko in Galicia demonstrated 